\title{
EFFECTS OF LIVE SACCHAROMYCES CEREVISIAE AND YEAST CELL WALL ON PERFORMANCE OF BROILER CHICK
}

\author{
Abdel-Aziz, M. F. ${ }^{(1)}$ Hemid, A. A. ${ }^{(2)}$; Masoud, M. S. ${ }^{(1)}$; \\ and El-Afifi, T. M. ${ }^{(1)}$ \\ 1) Regional Center for Food and Feed (RCFF), Agricultural Research Center \\ 2) Poultry Sciences Section, Faculty of Agriculture, Ain Shams University.
}

\begin{abstract}
The experiment was carried out to evaluate the effects of different levels life Saccharomyces cerevisiae and yeast cell wall individually or in combination on growth performance, of Ross unsexed broiler chicks from $0-36$ days of age. There were 15 dietary treatments and control. The results indicated that weight gain, feed intake and feed conversion ratio were significantly influenced by the addition of Saccharomyces cerevisiae with or without yeast cell wall.

The results suggest that supplementation of S. cerevisiae with or without yeast cell wall to diets have a positive influence for improving performance of broilers flock
\end{abstract}

Key words: Saccharomyces cerevisiae, yeast cell wall, performance, broiler.

\section{INTRODUCTION}

The U.S National Food Ingredient Association presented, probiotic (direct fed microbial) as a source of live naturally occurring microorganisms and this includes bacteria and yeast. Probiotic strains have been shown to inhibit pathogenic bacteria both in vitro and in vivo through several different mechanisms without a healthy gastrointestinal tract (Sims et al., 2004). The European ban urge to the development of alternative methods to promote health by replaced prebiotic or probiotic agents on the use of antibiotics in animal feed as a growth-promoting (Phillips, 2007; Rieder et al., 2013). 
The inclusion of yeast products to broilers diets can increase growth performance, improve intestinal morphology, promote the development of immune organs, stimulate intestinal immunoglobulin secretion, and prohibit the colonization of pathogenic bacteria (Santin et al., 2001; Gao et al.,2008; Morales-López et al., 2009; Haldar et al., 2011; Muthusamy et al., 2011; Reisinger et al., 2012).

Prebiotics are "non-digestible food ingredients that beneficially affect the host by selectively stimulating the growth and/or activity of one or a limited number of bacteria, most identified prebiotics are carbohydrates and oligosaccharides with different molecular structures normally occurring in the animal diet. Mannan-oligosaccharides have been used in the same manner as the prebiotics, they do not selectively enrich for beneficial bacterial populations. Mannan-oligosaccharide are able to bind to mannose-specific lectin of gram negative bacteria pathogens that express in their excretion from the intestine (Francesca Gaggìa et al., 2010).

Mannan oligosaccharides are polysaccharide-protein complexes 1,3/1,6 $\beta$ glucans are two major components of the yeast cell wall (Shashidhara and Devegowda, 2003; Ganner and Schatzmayr, 2012) that are indigestible to monogastric animals and can inhibit colonization of pathogenic microorganism in the intestinal tract by binding pathogenic bacteria which possess mannosespecific type-I fimbriae and by its prebiotic activity (Shoaf-Sweeney and Hutkins, 2008; Ganner and Schatzmayr, 2012). 
The objective of the present study was to evaluate the effect of life Saccharomyces cerevisiae and yeast cell wall on growth performance of broiler chicks.

\section{MATERIAS AND METHODS}

This study was carried out at Al-Nahda Poultry Farm Cairo-Alexandria desert road, Regional Center for Food and Feed (RCFF), Giza, Egypt during 2017. All chemical analyses were performed at the laboratories of the Regional Center for Food and Feed (RCFF), Agriculture Research Center, Giza, Egypt.

A total of 480 one-day old broiler chicks Ross 308 were equally divided into 16 treatment $\mathrm{Cn}=30,10$ in each replicate as shown in Table (1).

Table (1): Experimental diets.

\begin{tabular}{|c|c|}
\hline No. & Treatments per gm/ Kg Diet \\
\hline \hline Control & Negative control (no additive) \\
\hline T1 & 0.5 gm Yeast Cell wall \\
\hline T2 & 0.75 gm Yeast Cell wall \\
\hline T3 & 1.0 gm Yeast Cell wall \\
\hline T4 & 1.0 Life Yeast \\
\hline T5 & 1.0 Life Yeast +0.5 gm Yeast Cell wall \\
\hline T6 & 1.0 Life Yeast +0.75 gm Yeast Cell wall \\
\hline T7 & 1.0 Life Yeast +1.0 gm Yeast Cell wall \\
\hline T8 & 2.0 Life Yeast +0.5 gm Yeast Cell wall \\
\hline T9 & 2.0 Life Yeast +0.75 gm Yeast Cell wall \\
\hline T10 & 2.0 Life Yeast +1.0 gm Yeast Cell wall \\
\hline T11 & 3.0 Life Yeast \\
\hline T12 & 3.0 Life Yeast +0.5 gm Yeast Cell wall \\
\hline T13 & 3.0 Life Yeast +0.75 gm Yeast Cell wall \\
\hline T14 & 3.0 Life Yeast +1.0 gm Yeast Cell wall \\
\hline T15 & 12 days) grower $(13-24$ dass and fisher \\
\hline \hline
\end{tabular}

The chicks fed starter ( 1 - 12 days) grower (13 - 24 days) and finisher (25 - 36 days) diets. 
Diets were formulated to cover all nutrient requirements of broiler chicks according to ROSS nutrition supplement 2009 (Table 2). Live body weight (LBW), body weight gain (BWG), feed consumption (FC) and feed conversion ratio (FCR) were weekly determined.

All data were analyzed statistically by using the general linear model procedure of the statistical analyses system (SAS). Overall data were analyzing using one-way ANOVA test. Significant of different between groups was determined using Duncan multiple range test (Duncan 1955). The statistical model performed as follow:

$$
\mathbf{Y}_{\mathrm{ij}}=\boldsymbol{\mu}+\mathbf{T}_{\mathrm{i}}+\mathbf{E}_{\mathrm{ij}}
$$

Where: $Y_{i j}=$ is the experimental observation, $\mu=$ the overall Mean, $T_{i}=$ is the effect of the dietary treatment and $\mathrm{E}_{\mathrm{ij}}=$ random error. 
Table (2): Composition and calculated analysis of the used dies.

\begin{tabular}{|c|c|c|c|}
\hline Ingredients & Starter & Grower & Finisher \\
\hline Yellow corn $(7.5 \% \mathrm{CP})$ & 52.000 & 59.595 & 60.300 \\
\hline Soybean meal $(45.8 \% \mathrm{CP})$ & 32.000 & 27.500 & 27.200 \\
\hline Corn gluten meal $(60.8 \% \mathrm{CP})$ & 8.500 & 6.500 & 5.100 \\
\hline Vegetable Soybean oil & 3.000 & 2.900 & 4.390 \\
\hline Di-calcium phosphate & 2.000 & 1.666 & 1.448 \\
\hline Limestone & 1.100 & 0.770 & 0.675 \\
\hline Vit. \& Min. Mixture (1) & 0.400 & 0.300 & 0.300 \\
\hline Salt & 0.400 & 0.300 & 0.300 \\
\hline L-lysine- $\mathrm{HCl}$ & 0.350 & 0.288 & 0.136 \\
\hline DL-Methionine & 0.165 & 0.106 & 0.780 \\
\hline Choline chloride & 0.082 & 0.075 & 0.075 \\
\hline Total & 100 & 100 & 100 \\
\hline \multicolumn{4}{|l|}{ Calculated values } \\
\hline $\mathrm{CP} \%$ & 22.77 & 20.5 & 19.5 \\
\hline $\mathrm{ME}(\mathrm{KCal} / \mathrm{Kg})$ & 3026.07 & 3086 & 3167 \\
\hline Lysine \% & 1.360 & 1.190 & 1.050 \\
\hline Methionine \% & 0.580 & 0.480 & 0.430 \\
\hline Methionine + Cystine \% & 0.980 & 0.890 & 0.820 \\
\hline Cystine \% & 0.450 & 0.410 & 0.390 \\
\hline Calcium \% & 0.980 & 0.840 & 0.760 \\
\hline Available P \% & 0.380 & 0.420 & 0.380 \\
\hline \multicolumn{4}{|c|}{$\begin{array}{l}\text { Vitamins - minerals mixture supplied per kg of diet: Vit. (A), } 12000 \mathrm{I} . U ., \text { vit. (D3), } \\
2000 \mathrm{I} . \mathrm{U} \text {; vit. (E), } 10 \mathrm{mg} \text {; vit. (K3), } 2 \mathrm{mg} \text {; vit. (B1), } 1 \mathrm{mg} \text {; vit. (B2), } 5 \mathrm{mg} \text {; vit. (B6), } 1.5 \\
\mathrm{mg} \text {; vit. (B12), } 10 \mu \mathrm{g} \text {; Biotin, } 50 \mu \mathrm{g} \text {; Pantothenic acid, 10mg; Niacin, } 30 \mathrm{mg} \text {; Folic acid, } \\
1 \mathrm{mg} \text {; Manganese, } 60 \mathrm{mg} \text {; Zinc, } 50 \mathrm{mg} \text {; Iron, } 30 \mathrm{mg} \text {; Copper, } 10 \mathrm{mg} \text {; Iodine, } 1 \mathrm{mg} \text {; } \\
\text { Selenium, } 0.1 \mathrm{mg} \text { and Cobalt, } 0.1 \mathrm{mg} \text {. }\end{array}$} \\
\hline
\end{tabular}

\section{RESULTS AND DISCUSSION}

Data presented in table (3) for starter period from the 1st day to 12 days old showed that, there were no significant difference between treatments on weight gain, feed intake and feed conversion ratio, compared with control, Fig (1). 
Table (3): Effect of dietary treatments on BWG, FI and FCR of broiler chickens (1 - 12 days of age).

\begin{tabular}{|c|c|c|c|}
\hline \multirow{2}{*}{ TREAT. } & WG 1 & FI 1 & FCR 1 \\
\cline { 2 - 4 } & Mean \pm SE & Mean \pm SE & Mean \pm SE \\
\hline \hline Control & $0.221 \mathrm{a}$ & $0.253 \mathrm{a}$ & $1.15 \mathrm{a}$ \\
\hline T1 & $0.218 \mathrm{a}$ & $0.252 \mathrm{a}$ & $1.15 \mathrm{a}$ \\
\hline T2 & $0.232 \mathrm{a}$ & $0.262 \mathrm{a}$ & $1.13 \mathrm{a}$ \\
\hline T3 & $0.242 \mathrm{a}$ & $0.277 \mathrm{a}$ & $1.15 \mathrm{a}$ \\
\hline T4 & $0.224 \mathrm{a}$ & $0.259 \mathrm{a}$ & $1.16 \mathrm{a}$ \\
\hline T5 & $0.232 \mathrm{a}$ & $0.265 \mathrm{a}$ & $1.14 \mathrm{a}$ \\
\hline T6 & $0.222 \mathrm{a}$ & $0.260 \mathrm{a}$ & $1.17 \mathrm{a}$ \\
\hline T7 & $0.219 \mathrm{a}$ & $0.260 \mathrm{a}$ & $1.19 \mathrm{a}$ \\
\hline T8 & $0.223 \mathrm{a}$ & $0.268 \mathrm{a}$ & $1.21 \mathrm{a}$ \\
\hline T9 & $0.230 \mathrm{a}$ & $0.257 \mathrm{a}$ & $1.13 \mathrm{a}$ \\
\hline T10 & $0.211 \mathrm{a}$ & $0.247 \mathrm{a}$ & $1.18 \mathrm{a}$ \\
\hline T11 & $0.212 \mathrm{a}$ & $0.255 \mathrm{a}$ & $1.21 \mathrm{a}$ \\
\hline T12 & $0.229 \mathrm{a}$ & $0.262 \mathrm{a}$ & $1.15 \mathrm{a}$ \\
\hline T13 & $0.231 \mathrm{a}$ & $0.274 \mathrm{a}$ & $1.19 \mathrm{a}$ \\
\hline T14 & $0.230 \mathrm{a}$ & $0.258 \mathrm{a}$ & $1.12 \mathrm{a}$ \\
\hline T15 & $0.223 \mathrm{a}$ & $0.275 \mathrm{a}$ & $1.24 \mathrm{a}$ \\
\hline MSE & 0.010 & 0.010 & 0.035 \\
\hline
\end{tabular}

WG 1: Weight gain, FI 1: Feed intake, FCR 1: Feed conversation ratio, T1, T2......T15: Treatments, ${ }^{\text {a }}$ :

Santin et al., (2001) showed higher body weight gain and better feed conversion for the birds fed Saccharomyces cerevisiae cell walls supplemented diets at 7 days of age. KOC et al., (2010) reported that, inoculation of Saccharomyces cerevisiae in the diet has been improvement the bird performance and decreased mortality. Tagang Aluwong et al., (2013) observed a highly significant performance in birds fed diets supplemented with 
Saccharomyces cerevisiae compared with control in $1^{\text {st }}$ week and $2^{\text {nd }}$ week of age.

This improvement may be due to the balanced microbial population in the gastrointestinal tract (Thongsong et al., 2008) and the trophic effect of this product on the intestinal mucosa (Santin et al., 2001) which has play an important role in the health and performance of the broilers during the first 7 days of a chicken's life. Flemming et al., (2004) concluded that, the noninclusion of any growth promoters in broiler diets may cause production losses.

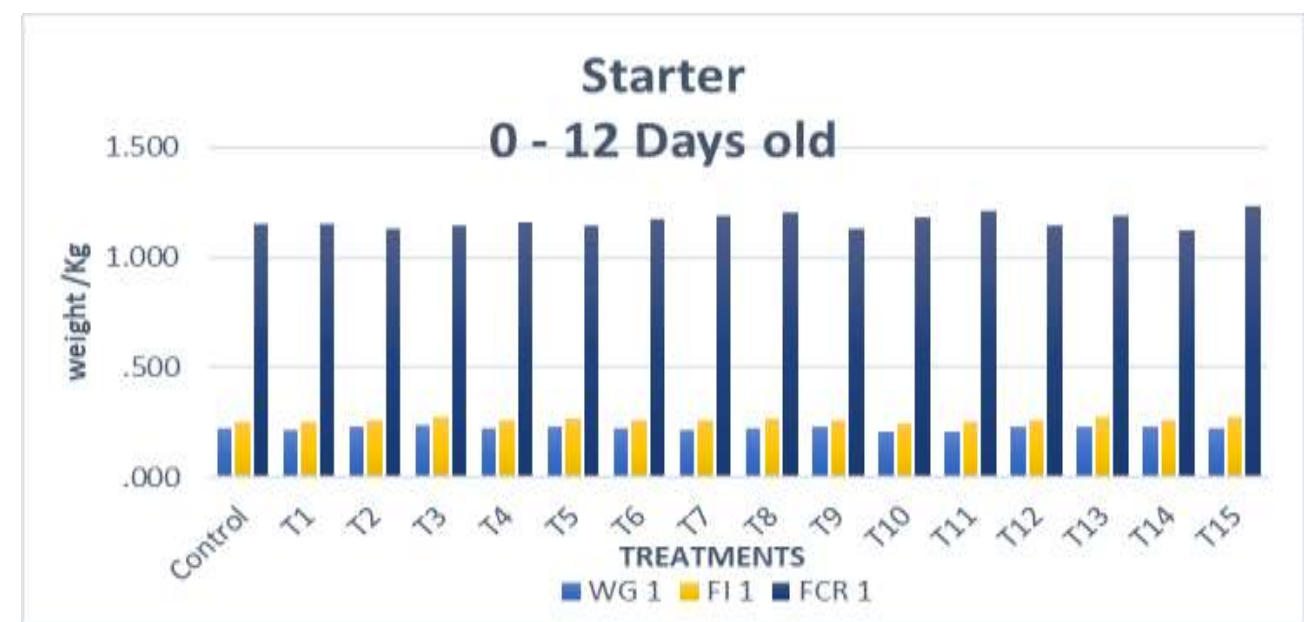

Fig. (1): Effect of dietary treatments on BWG, F1 and FCR of broiler chickens (1 -12 days of age)

The results in table (4) and Fig (2) in grower period form 13 days to 24 days old recorded high weight gain for T3 (0.813) for chicks feed basil diet supplemented with 1.0 gm yeast cell wall compared with control (0.690), and there was significant difference between treatments. The lowest weight gain was recorded for T11 (0.701) which fed diet contain 2.0 gm life yeast plus $1.0 \mathrm{gm}$ yeast cell wall compared with control (0.690). These results agree with 
Muthusamy et al., (2011) who study the effects of diet supplemented with 1 $\mathrm{gm} / \mathrm{kg}$ of either whole Saccharomyces cerevisiae yeast and yeast cell wall on broilers, and concluded that, yeast cell wall may be a better dietary tool than the whole yeast cell as a performance enhancer for broilers.

KOC et al., (2010) supported that Saccharomyces cerevisiae in the diet has been shown an improvement the bird performance and decreased mortality. This improvement may be related to the balanced microbial population in the gastrointestinal tract (Thongsong et al., 2008, Tagang Aluwong et al., 2013) which has play an important role in the health and performance and increased the ability to improve immune function and intestinal oxidative status of the broilers (Li et al., 2016).

On other side the results showed that, there were no significant difference between treatments on feed intake and feed conversion ratio, compared with control. The FCR, measured as $\mathrm{kg}$ feed/kg body weight gain, is presented numerical, but not significant, differences between treatments. 
Table (4): Effect of dietary treatments on BWG, FI and FCR of broiler chickens (13 - 24 days of age).

\begin{tabular}{|c|c|c|c|}
\hline \multirow{2}{*}{ TREAT. } & WG 2 & FI 2 & FCR 2 \\
\hline & Mean \pm SE & Mean \pm SE & Mean \pm SE \\
\hline Control & $0.690^{\mathrm{d}}$ & $0.940^{\mathrm{a}}$ & $1.36^{\mathrm{a}}$ \\
\hline $\mathrm{T} 1$ & $0.720^{\text {bcd }}$ & $0.985^{\mathrm{a}}$ & $1.37^{\mathrm{a}}$ \\
\hline $\mathrm{T} 2$ & $0.731^{\text {abcd }}$ & $0.933^{\mathrm{a}}$ & $1.28^{\mathrm{a}}$ \\
\hline $\mathrm{T} 3$ & $0.813^{\mathrm{a}}$ & $1.080^{\mathrm{a}}$ & $1.33^{\mathrm{a}}$ \\
\hline $\mathrm{T} 4$ & $0.756^{\mathrm{abcd}}$ & $1.035^{\mathrm{a}}$ & $1.37^{\mathrm{a}}$ \\
\hline $\mathrm{T} 5$ & $0.779^{a b c}$ & $0.983^{\mathrm{a}}$ & $1.26^{\mathrm{a}}$ \\
\hline T6 & $0.770^{\mathrm{abcd}}$ & $1.027^{\mathrm{a}}$ & $1.33^{\mathrm{a}}$ \\
\hline T7 & $0.762^{\text {abcd }}$ & $1.029^{\mathrm{a}}$ & $1.35^{\mathrm{a}}$ \\
\hline $\mathrm{T} 8$ & $0.739^{\text {abcd }}$ & $0.967^{\mathrm{a}}$ & $1.31^{\mathrm{a}}$ \\
\hline T9 & $0.734^{\mathrm{abcd}}$ & $0.968^{\mathrm{a}}$ & $1.32^{\mathrm{a}}$ \\
\hline T10 & $0.724^{\text {bcd }}$ & $1.000^{\mathrm{a}}$ & $1.39^{\mathrm{a}}$ \\
\hline T11 & $0.701^{\mathrm{cd}}$ & $0.945^{\mathrm{a}}$ & $1.35^{\mathrm{a}}$ \\
\hline T12 & $0.797^{\mathrm{ab}}$ & $1.021^{\mathrm{a}}$ & $1.28^{\mathrm{a}}$ \\
\hline T13 & $0.779^{\mathrm{abc}}$ & $0.990^{\mathrm{a}}$ & $1.27^{\mathrm{a}}$ \\
\hline T14 & $0.754^{\mathrm{abcd}}$ & $0.986^{\mathrm{a}}$ & $1.31^{\mathrm{a}}$ \\
\hline T15 & $0.804^{\mathrm{ab}}$ & $1.000^{\mathrm{a}}$ & $1.25^{\mathrm{a}}$ \\
\hline MSE & 0.016 & 0.030 & 0.032 \\
\hline
\end{tabular}

WG 2: Weight gain, FI 2: Feed intake, FCR 2: Feed conversation ratio, T1, T2,......T15: Treatments, ${ }^{\mathrm{a}}$ :

The results in table (5) and Fig (3) in finisher period form 25 days to 36 days old recorded that, the high weight gain for T7 (0.937) that feed basil diet contents of $1.0 \mathrm{gm}$ life yeast plus 1.0 gm yeast cell wall compared with control (0.715), and there was significant difference between treatments. The lowest results were recorded for T1 (0.809) or control (0.715) which fed diets supplemented with $0.5 \mathrm{gm}$ yeast cell wall or basel diet. 
J. Environ. Sci.

Institute of Environmental Studies and Research - Ain Shams University

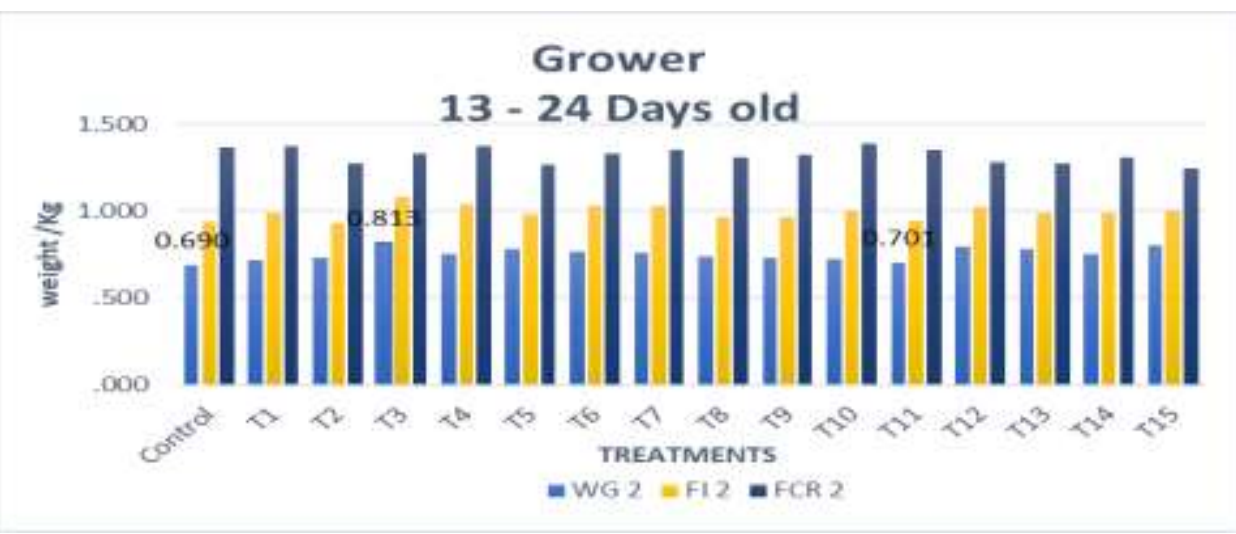

Fig. (2): Effect of dietary treatments on BWG, FI and FCR of broiler chickens (13 - 24 days of age).

The results agree with Gao et al., (2008); and Fasina and Olowo (2013) reveled that, growth performance of broilers was not affected by diets containing at least $750 \mathrm{mg} / \mathrm{kg}$ of yeast compared to the control group during day 0 to 21 but the effect on growth performance was found at the later period day 22 to 42 .

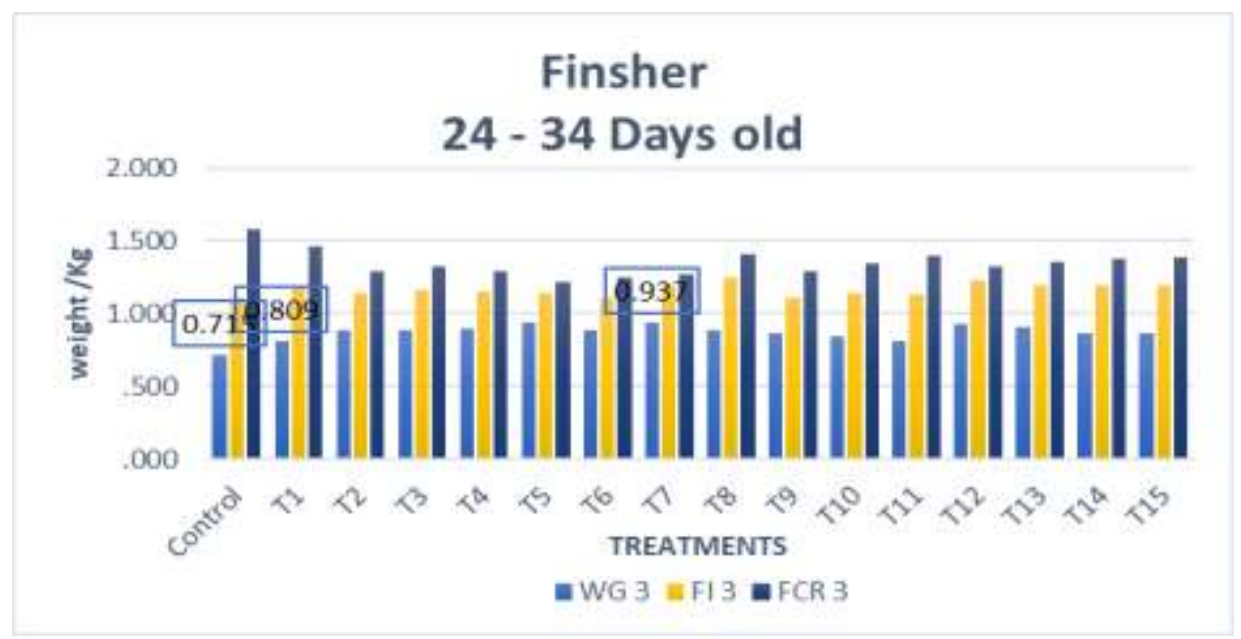

Fig. (3): Effect of dietary treatments on BWG, FI and FCR of broiler chickens (25 - 36 days of age). 
There was no significant difference between treatments on feed intake compared with control. Otherwise results of feed conversion ratio on T5 (1.22) and T6 (1.25) were more significant than control (1.58). Zhang et al., (2005) showed that, birds feed with yeast cell wall from 0 to 3 weeks of age, recoded a lower feed/gain ratio, whereas the birds feed with wall yeast at 4 to 5 weeks of age gave a lower feed/gain ratio compared with the control.

Table (5): Effect of dietary treatments on BWG, FI and FCR of broiler chickens (25 - 36 days of age).

\begin{tabular}{|c|c|c|c|}
\hline \multirow{2}{*}{ TREAT. } & WG 3 & FI 3 & FCR 3 \\
\hline & Mean \pm SE & Mean \pm SE & Mean \pm SE \\
\hline Control & $0.715^{\mathrm{d}}$ & $1.114^{\mathrm{a}}$ & $1.58^{\mathrm{a}}$ \\
\hline $\mathrm{T} 1$ & $0.809^{\mathrm{cd}}$ & $1.178^{\mathrm{a}}$ & $1.46^{\mathrm{ab}}$ \\
\hline $\mathrm{T} 2$ & $0.886^{a b c}$ & $1.141^{\mathrm{a}}$ & $1.29^{\mathrm{ab}}$ \\
\hline T3 & $0.889^{a b c}$ & $1.167^{\mathrm{a}}$ & $1.32^{\mathrm{ab}}$ \\
\hline $\mathrm{T} 4$ & $0.900^{\mathrm{abc}}$ & $1.156^{\mathrm{a}}$ & $1.29^{\mathrm{ab}}$ \\
\hline T5 & $0.936^{\mathrm{ab}}$ & $1.141^{\mathrm{a}}$ & $1.22^{b}$ \\
\hline T6 & $0.889^{a b c}$ & $1.113^{\mathrm{a}}$ & $1.25^{b}$ \\
\hline $\mathrm{T} 7$ & $0.937^{\mathrm{a}}$ & $1.190^{\mathrm{a}}$ & $1.27^{\mathrm{ab}}$ \\
\hline $\mathrm{T} 8$ & $0.884^{a b c}$ & $1.245^{\mathrm{a}}$ & $1.41^{\mathrm{ab}}$ \\
\hline T9 & $0.865^{a b c}$ & $1.106^{\mathrm{a}}$ & $1.29^{\mathrm{ab}}$ \\
\hline $\mathrm{T} 10$ & $0.846^{\mathrm{abc}}$ & $1.140^{\mathrm{a}}$ & $1.35^{\mathrm{ab}}$ \\
\hline T11 & $0.810^{b c d}$ & $1.133^{\mathrm{a}}$ & $1.40^{\mathrm{ab}}$ \\
\hline T12 & $0.929^{a b c}$ & $1.229^{\mathrm{a}}$ & $1.32^{\mathrm{ab}}$ \\
\hline T13 & $0.904^{a b c}$ & $1.198^{\mathrm{a}}$ & $1.35^{\mathrm{ab}}$ \\
\hline T14 & $0.866^{a b c}$ & $1.191^{\mathrm{a}}$ & $1.38^{\mathrm{ab}}$ \\
\hline T15 & $0.859^{\mathrm{abc}}$ & $1.190^{\mathrm{a}}$ & $1.39^{\mathrm{ab}}$ \\
\hline MSE & 0.024 & 0.041 & 0.062 \\
\hline
\end{tabular}

WG 3: Weight gain, FI 3: Feed intake, FCR 3: Feed conversation ratio, T1, T2,......T15: Treatments, ${ }^{\mathrm{a}}$ : 
These results are in line with the findings of KOC et al., (2010). Saccharomyces cerevisiae in the diet has been shown an improvement at the bird performance and decreased mortality. Also, agreement with the results recorded that, a significant difference between treatments in body weight compared with control in week 4 by (Tagang Aluwong et al., 2013).

This improvement may be related with the balanced microbial population in the gastrointestinal tract which has played an important role in the health and performance of the broilers (Thongsong et al., 2008, Tagang Aluwong et al., 2013) or increased antibody levels and reduced intestinal pathogenic bacterial numbers (Xiangyu Tian et al., 2016).

The results in table (6) and Fig (4) for bird's life form 1st days to 36 days old showed that, the high weight gain for T12, T5, T3 and T7 (1.679, 1.667, 1.655 and 1.652) respectively, that feed basil diet contents of $3.0 \mathrm{gm}$ life yeast only, 1.0 gm life yeast plus 0.5 gm yeast cell wall, 1.0 gm yeast cell wall and 1.0 gm life yeast plus 1.0 gm yeast cell wall respectively compared with control (1.357), and there was significant difference between treatments. the bad result between treatments was recorded at T1 and T11 (1.482 and 1.464) respectively, for bird's diet contents of $0.5 \mathrm{gm}$ Yeast Cell wall only and $2.0 \mathrm{gm}$ Life Yeast plus 1.0 gm yeast cell wall compared with control (1.357).

The results were similar with Zhang et al., (2005) who recorded that, from 0 to 5 weeks of age, wall yeast and yeast cell wall gave higher body weight gains than the control. Also, in line with the findings of KOC et al., (2010). Saccharomyces cerevisiae in the diet has been shown an improvement at the bird performance and decreased mortality. Also, Reisinger et al., (2012) observed a 
positive influence by adding supplementation of yeast. Also there were agreement with the results recorded a significant difference between treatments in body weight compared with control at four week of age (Tagang Aluwong et al., 2013).

Table (6): Effect of dietary treatments on BWG, FI and FCR of broiler chickens overall for ( 1 - 36 days of age).

\begin{tabular}{|c|c|c|c||}
\hline \multirow{2}{*}{ TREAT. } & WG 4 & FI 4 & FCR 4 \\
\cline { 2 - 4 } & Mean \pm SE & Mean \pm SE & Mean \pm SE \\
\hline \hline Control & $1.357^{\mathrm{c}}$ & $2.307^{\mathrm{a}}$ & $1.71^{\mathrm{a}}$ \\
\hline $\mathrm{T} 1$ & $1.482^{\mathrm{bc}}$ & $2.415^{\mathrm{a}}$ & $1.63^{\mathrm{ab}}$ \\
\hline $\mathrm{T} 2$ & $1.570^{\mathrm{ab}}$ & $2.336^{\mathrm{a}}$ & $1.49^{\mathrm{bc}}$ \\
\hline $\mathrm{T} 3$ & $1.655^{\mathrm{a}}$ & $2.524^{\mathrm{a}}$ & $1.53^{\mathrm{abc}}$ \\
\hline $\mathrm{T} 4$ & $1.609^{\mathrm{ab}}$ & $2.450^{\mathrm{a}}$ & $1.52^{\mathrm{abc}}$ \\
\hline $\mathrm{T} 5$ & $1.667^{\mathrm{a}}$ & $2.388^{\mathrm{a}}$ & $1.43^{\mathrm{c}}$ \\
\hline $\mathrm{T} 6$ & $1.612^{\mathrm{ab}}$ & $2.399^{\mathrm{a}}$ & $1.49^{\mathrm{bd}}$ \\
\hline $\mathrm{T} 7$ & $1.652^{\mathrm{a}}$ & $2.479^{\mathrm{a}}$ & $1.50^{\mathrm{bc}}$ \\
\hline $\mathrm{T} 8$ & $1.576^{\mathrm{ab}}$ & $2.480^{\mathrm{a}}$ & $1.58^{\mathrm{abc}}$ \\
\hline $\mathrm{T} 9$ & $1.552^{\mathrm{ab}}$ & $2.331^{\mathrm{a}}$ & $1.51^{\mathrm{abc}}$ \\
\hline $\mathrm{T} 10$ & $1.523^{\mathrm{ab}}$ & $2.387^{\mathrm{a}}$ & $1.57^{\mathrm{abc}}$ \\
\hline $\mathrm{T} 11$ & $1.464^{\mathrm{bc}}$ & $2.333^{\mathrm{a}}$ & $1.59^{\mathrm{abc}}$ \\
\hline $\mathrm{T} 12$ & $1.679^{\mathrm{a}}$ & $2.512^{\mathrm{a}}$ & $1.50^{\mathrm{bc}}$ \\
\hline $\mathrm{T} 13$ & $1.619^{\mathrm{ab}}$ & $2.461^{\mathrm{a}}$ & $1.52^{\mathrm{abc}}$ \\
\hline $\mathrm{T} 14$ & $1.574^{\mathrm{ab}}$ & $2.435^{\mathrm{a}}$ & $1.55^{\mathrm{abc}}$ \\
\hline $\mathrm{T} 15$ & $1.616^{\mathrm{ab}}$ & $2.465^{\mathrm{a}}$ & $1.53^{\mathrm{abc}}$ \\
\hline $\mathrm{M} 5 \mathrm{n}$ & $0.030^{\mathrm{a}}$ & $0.062^{\mathrm{a}}$ & 0.038 \\
\hline \hline
\end{tabular}

WG 4: Weight gain, FI 4: Feed intake, FCR 4: Feed conversation ratio, T1, T2,......T15: Treatments, ${ }^{\text {a }}$ :

This improvement may be related with the balanced microbial population in the gastrointestinal tract which has an important role in the health and performance of the broilers (Thongsong et al., 2008; Tagang Aluwong et al., 
(2013) and Reisinger et al., (2012) who decided that, Apoptotic enterocytes were decreased by Supplementation of yeast. The improved health might have increased the absorption area in the gut (Santin et al., 2001).

On other side the results showed that, there were no significant difference between treatments on feed intake compared with control. Otherwise results highly recorded of feed conversion ratio decreased on T5 (1.43) and more significant than treatments compared with control (1.71) in the fifth week of the experiment. These results agree with (Tagang Aluwong et al., 2013).

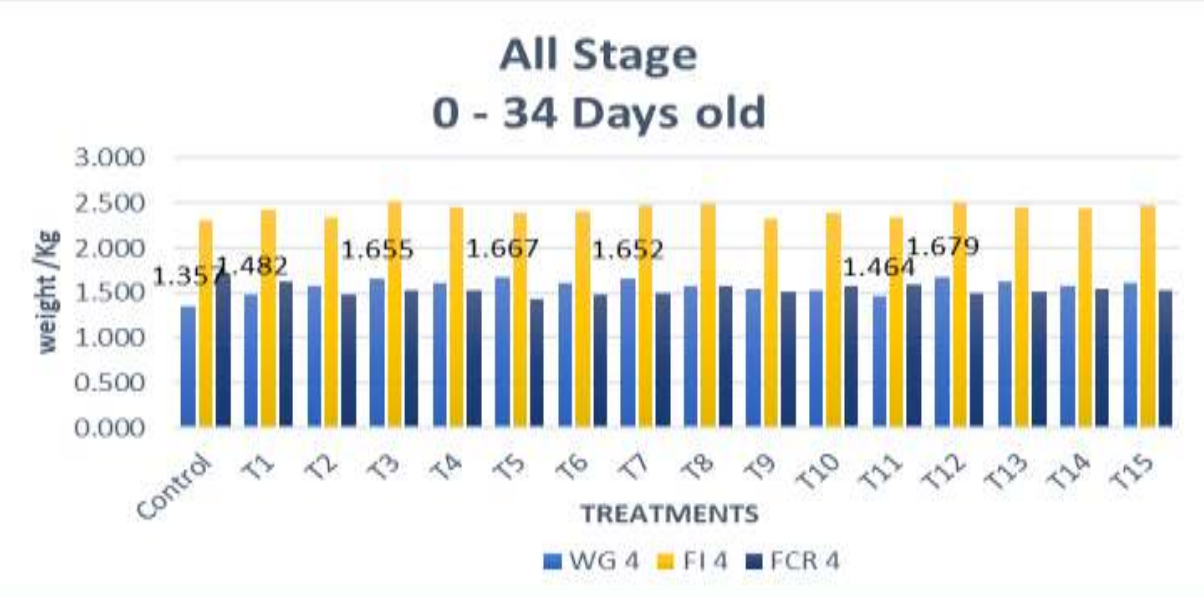

Fig. (4): Effect of dietary treatments on BWG, FI and FCR of broiler chickens overall for ( 1 - 36 days of age)

\section{REFERENCES}

Duncan, D. B. (1955): Multiple range and multiple F test. Biometrics, 11: 1-42.

Fasina, Y.O. and Olowo, Y.L. (2013): Effect of a commercial yeast-based product (Maxigens) on intestinal villi morphology and growth performance of broiler chickens. Int. J. Poult. Sci. 12: 9-14. 
Flemming, J. S., Freitas, J. R, S., Fontoura, P., Montanhini Neto, R. and Arruda, J. S. (2004): Use of Mannanoligosaccharides in Broiler Feeding. Brazilian J. Poult. Sci. 6(3), 159 - 161.

Francesca Gaggìa, Paola Mattarelli, and Bruno Biavati. (2010): Probiotics and prebiotics in animal feeding for safe food production. Int. J. Food Microbiology 141: S15-S28.

Ganner Anja and Gerd Schatzmayr. (2012): Capability of yeast derivatives to adhere enteropathogenic bacteria and to modulate cells of the innate immune system. Appl. Microbiol Biotechnol. 95: 289-297.

Gao, J., Zhang, H.J., Yu, S.H., Wu, S.G., Yoon, I., Quigley, J., Gao, Y.P. and Qi, G.H. (2008): Effects of yeast culture in broiler diets on performance and immunomodulatory functions. Poultry Science, 87: 1377-1384.

Haldar, S., Ghosh, T.K., Toshiwati, and Bedford, M.R. (2011): Effects of yeast (Saccharomyces cerevisiae) and yeast protein concentrate on production performance of broiler chickens exposed to heat stress and challenged with Salmonella enteritidis. Anim. Feed Sci. Technol. 168: 61-71.

KOC, F., SAMLI, H., OKUR, A., OZDUVEN, M., AKYUREK, H. and SENKOYLU N. (2010): Effects of Saccharomyces cerevisiae and/or mannanoligosaccharide on performance, blood parameters and intestinal microbiota of broiler chicks. Bulg. J. Agric. Sci., 16: 643650.

Li, X.H., Chen, Y.P., Cheng, Y.F., Yang, W.L., Wen, C. and Zhou, Y.M. (2016): Effect of yeast cell wall powder with different particle sizes on the growth performance, serum metabolites, immunity and oxidative status of broilers. J. Animal Feed sci. 212: 81-89.

Morales-Lopez, R., Auclair, E., Garcia, F., Esteve-Garcia, E., and Brufau, J., (2009): Use of yeast cell walls; beta-1,3/1,6-glucans; and mannoproteins in broiler chicken diets. J. Poult. Sci. 88: 601-607. 
Muthusamy, N., Haldar, S., Ghosh, T.K. and Bedford, M.R. (2011): Effects of hydrolysed Saccharomyces cerevisiae yeast and yeast cell wall components on live performance, intestinal histo-morphology and humoral immune response of broilers. British Poult. Sci. 52(6), 694703.

Phillips, I. (2007): Withdrawal of growth-promoting antibiotics in Europe and its effects in relation to human health. Int. J. Antimicrob. Agents 30: 101-107.

Reisinger Nicole, Anja Ganner, Sabine Masching, Gerd Schatzmayr, and Todd J. Applegate. (2012): Efficacy of a yeast derivative on broiler performance, intestinal morphology and blood profile. Livestock Science 143: 195-200.

Rieder, A., Grimmer, S., Aachmann, F.L., Westereng, B., Kolset, S.O. and Knutsen, S.H. (2013): Generic tools to assess genuine carbohydrate specific effects on in vitro immune modulation exemplified by bglucans. Carbohydr. Polym. 92: 2075-2083.

Santin, E., Maiorka, A., Macari, M., Grecco, M., Sanchez, J.C., Okada, T.M., and Myasaka, A.M. (2001): Performance and intestinal mucosa development of broiler chickens fed diets containing Saccharomyces cerevisiae cell wall. J. Appl. Poult. Res. 10: 236-244.

SAS (1999): SAS statistics User's Guide. Statistical Analytical System. 5th Rev. Ed., SAS Institute Inc., Cary, NC.

Shashidhara, R.G. and Devegowda, G. (2003): Effect of dietary mannan oligosaccharide on broiler breeder production traits and immunity. J. Poult. Sci. 82: 1319-1325.

Shoaf-Sweeney, K.D. and Hutkins, R.W. (2008): Chapter 2 adherence, antiadherence, and oligosaccharides: preventing pathogens from sticking to the host. Adv. Food Nutr. Res. 55: 101-161.

Sims, M.D., Dawson, K.A., Newman, K.E., Spring, P. and Hoogell, D.M. (2004): Effects of dietary mannan oligosaccharide, bacitracin methylene disalicylate, or both on the live performance and intestinal microbiology of turkeys. J. Poult. Sci. 83: 1148-1154. 
Tagang Aluwong, Mohammed Kawu, Moshood Raji, Tavershima Dzenda, Felix Govwang, Victor Sinkalu and Joseph Ayo. (2013): Effect of Yeast Probiotic on Growth, Antioxidant Enzyme Activities and Malondialdehyde Concentration of Broiler Chickens. J. antioxidants 2(4): 326-339.

Thongsong, B., Kalandakanond-Thongsong, S. and Chavananikul, V. (2008): Effects of the addition of probiotic containing both bacteria and yeast or an antibiotic on performance parameters, mortality rate and antibiotic residue in broilers. J. Vet. Med., 38 (1): 17-26.

Xiangyu Tian, Yujing Shao, Zhong Wang and Yuming Guo. (2016): Effects of dietary yeast $\beta$-glucans supplementation on growth performance, gut morphology, intestinal Clostridium perfringens population and immune response of broiler chickens challenged with necrotic enteritis. J. Ani. Feed sci. 215(2): 144-155.

Zhang, A. W., Lee, B. D., Lee, S. K., Lee, K. W., An G. H., Song, K. B. and Lee, C. H. (2005): Effects of Yeast (Saccharomyces cerevisiae) Cell Components on Growth Performance, Meat Quality, and Ileal Mucosa Development of Broiler Chicks. J. Poult. Sci 84:1015-1021. 


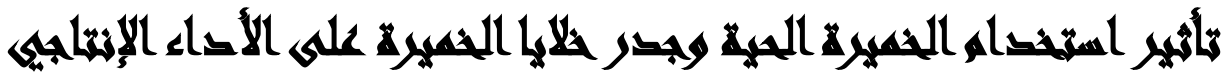

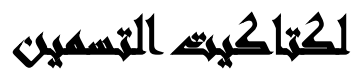

\section{[}

محمود فاروق عبد العزيز(')- علاء الدين عبد السلام حميد (†)- محمد سيد مسعود (')

طارق محمد العفيفى (')

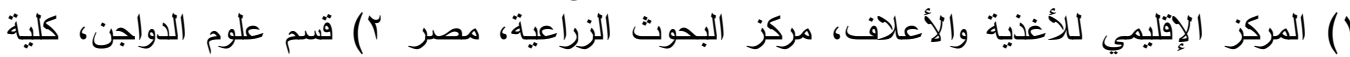

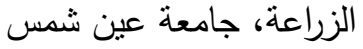

\section{المستخلص}

أجريت هذه التجربة لنقييم آثز استخدام الخميرة الحية وجدار خلايا الخميرة على الأداء الإنتاجي

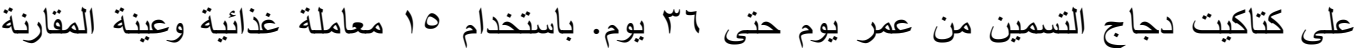

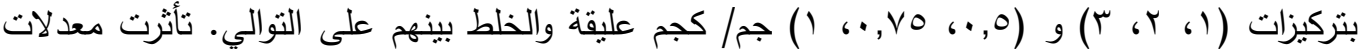

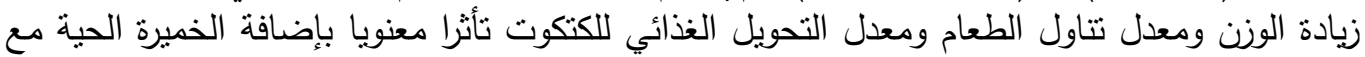
أو بدون جدار الخلية الخميرة. وتثير النتائج إلى أن الإضافات العلفية باستخدام الخميرة الحية مع أو بدون جدار خلايا الخميرة إلى المقررات الغذائية لها تأثثير إيجابي لتحسين الأداء لقطيع دجاج التسمين. 